DOI: $10.21802 /$ artm.2019.2.10.14.

УДК 616-056.2 616.12-008.46+616.127-005.8

\title{
ОСОБЛИВОСТІ ТОЛЕРАНТНОСТІ ДО ФІЗИЧНИХ НАВАНТАЖЕНЬ В ПОСТІНФАРКТНОМУ ПЕРІОДІ ЗАЛЕЖНО ВІД НАЯВНОСТІ ДЕКОМПЕНСАЦЇ̈ СЕРЦЕВОЇ НЕДОСТАТНОСТІ
}

\author{
І.П. Вакалюк, Х.В. Левандовська \\ Івано-Франківський начіональний медичний університет, \\ кафедра внутрішньої медищини №2 та медсестринства, м. Івано-Франківськ, Украйна, \\ ORCID ID: 0000-0002-4430-6816, ORCIDID: 0000-0003-3259-7940, \\ e-mail:levandovska87@ukr.net
}

Резюме. Ціль. Оцінити фізичну активність та доцільність використання тесту шестихвилинної ходьби у хворих з декомпенсованою СН у ранньому та пізньому постінфарктному періоді на фоні показників натрійуретичного пропептиду типу $\mathrm{B}$.

Матеріали і методи дослідження. Було обстежено 160 пацієнтів з перенесеним інфарктом міокарда. Хворих було рандомізовано в 2 групи, залежно від наявності ознак декомпенсованої хронічної СН. Досліджені групи були однорідними за віком, статтю, важкістю перебігу захворювання, тривалістю постінфарктного періоду, наявністю клінічних проявів декомпенсації.

Результати дослідження та їх обговорення. Впродовж вивчення клінічних та електрокардіологічних ознак виконання фізичних навантажень, таких як депресія сегменту ST, стенокардія, задишка, симптоми з боку центральної нервової системи, було виявлено значне погіршення стану пацієнтів з діагнозом Q-QS та не-Q IM, ускладненим декомпенсованою СН. У результаті аналізу ТШХ було з'ясовано, що наявність декомпенсованої $\mathrm{CH}$ значно погіршує показники цієї навантажувальної проби. В осіб з ознаками декомпенсованої СН мали місце вірогідно вищі рівні NT-proBNP у сироватці крові і склали $(850,54 \pm 20,51) \Pi г /$ мл $(\mathrm{p} \leq 0,05)$ в порівнянні 3 першою групою $(428,5 \pm 6,81)$ пг/мл $(\mathrm{p} \leq 0,05)$.

Висновки. У ході роботи встановлено, що неадекватна відповідь на дозовані фізичні навантаження, високий рівень NT-proBNP можуть бути корисними не тільки для ранньої діагностики та прогнозування виникнення декомпенсованої СН в ранньому та пізньому постінфарктному періоді, але і для прийняття рішення про оптимальне подальше диспансерне лікування такого контингенту хворих та рішення про виписку після госпіталізації.

Ключові слова: тест з шестихвилинною ходьбою, декомпенсована серцева недостатність, інфаркт міокарда, натрійуретичний пропептид типу В.

Вступ. Незважаючи на покращення лікування та профілактики $\mathrm{CH}$ залишається основною причиною захворюваності та смертності по всьому світу [14]. Попри те, що існує низка терапевтичних стратегій для лікування пацієнтів з хронічною серцевою недостатністю та ії декомпенсацією, засмучує той факт, що протягом 5 років, після вперше встановленого діагнозу, особливо в постінфарктному періоді, смертність складає 50\% [11, 17].

Синдром СН влучно порівнюють з айсбергом. У видимій частині представлені випадки ХСН серед населення: більшість таких хворих спостерігається у лікарів первинної медичної ланки та консультуються кардіологами. Велика, невидима частина, «нижче рівня води», представляе собою приховану $\mathrm{CH}$, 3 асимптоматичною дисфункцією лівого шлуночка (ЛШ), яка має здатність до швидкого прогресування та декомпенсації без адекватного лікування та вчасного діагностування.

Тест 3 шестихвилинною ходьбою (ТШХ) $є$ способом оцінки фізичної активності, що високо корелює 3 результатами таких навантажувальних проб, як велоергометрія та тредміл, та використову- ється у щоденній лікарській практиці для об’єктивізації функціонального класу (ФК) СН [1].

Проби 3 дозованим фізичним навантаженням є одними із основних прогностичних факторів, які використовуються для оцінки важкості перебігу хронічної $\mathrm{CH}$, появи іiі декомпенсації [16]. ТШХ відрізняється простотою та доступністю. Він є тестом, який найчастіше застосовують для оцінки толерантності до фізичного навантаження [2]. Спочатку тест використовувався для діагностики такого захворювання як хронічне обструктивне захворювання легень, та згодом зазнав широкого вжитку і серед інших патологій із хронічним перебігом процесу, зокрема і при СН [8]. На показники ТШХ впливають ряд факторів, зокрема важкість $\mathrm{CH}$, супутні захворювання, навіть вербальне заохочення пацієнта при проходженні відповідної дистанції [9]. Найважливішою перевагою тесту $\epsilon$ можливість оцінити прогноз функціональних змін пацієнта [18]. Відстань, яку пацієнт може подолати протягом 6 хвилин, традиційно вважається відображенням функціональних можливостей пацієнта [6] та служить об'єктивною оцінкою його функціонального класу [4]. 
На сьогодні визначення NT-proBNP сироватки крові необхідно використовувати для діагностики CH та ії декомпенсації і це являється I класом доказовості згідно з рекомендаціями Американської Асоціації Серця (АНА)/Американського Коледжу Кардіології (АСС) [13]. Натрійуретичні пептиди також служать предикторами декомпенсації СН. Постійне підвищення NT-proBNP пов'язують із зростанням смертності та захворюваності з приводу серцевої недостатності, повторних госпіталізацій [9].

Обгрунтування дослідження. Пацієнти 3 ознаками декомпенсованої СН після перенесеного гострого інфаркту міокарда характеризуються як функціональними порушеннями, так і неадекватною імунологічною відповіддю на фізичні навантаження. ТШХ є стандартизованим методом кількісного визначення функціональної спроможності пацієнтів 3 $\mathrm{XCH}$ та іiі декомпенсацією. Толерантність до фізичних навантажень є важливим симптомом маніфестації $\mathrm{XCH}$ [12], який може відображати ступінь декомпенсації $\mathrm{CH}$. Однак взаємозв'язок між цим тестом та імуноферментними змінами натрійуретичного пропептиду типу В, зокрема у пацієнтів із систолічною дисфункцією ЛШ, з'ясовано недостатньо. Знання цих взаємовідношень може забезпечити патофізіологічне розуміння гемодинамічної основи толерантності до фізичних навантажень. Максимальну дистанцію, яку пацієнт подолав протягом 6 хвилин, широко використовують для оцінки функціональних порушень при $\mathrm{XCH}$, як предиктор загальної причини смертності внаслідок СН [16]. Саме тому, цей тест може бути важливим інструментом для стратифікації ризику розвитку декомпенсованої СН в ранньому та пізньому постінфарктному періоді, оскільки прогностична цінність ТШХ, особливо у поєднанні з іншими клінічними та гемодинамічними показниками, вивчена недостатньо [3, 5].

Мета дослідження. Оцінити фізичну активність та доцільність використання ТШХ у хворих 3 декомпенсованою $\mathrm{CH}$ у ранньому та пізньому постінфарктному періоді на фоні показників натрійуретичного пропептиду типу В.

Матеріали і методи дослідження. Дослідження виконано на базі інфарктного відділення №2 Івано-Франківського обласного клінічного кардіологічного центру та кафедри внутрішньої медицини №2 та медсестринства Івано-Франківського національного медичного університету. Було обстежено 160 хворих із перенесеним IM, середній вік пацієнтів склав $(56,67 \pm 5,72)$ роки. Хворих було рандомізовано в 2 групи, залежно від наявності ознак декомпенсованої хронічної СН II А-Б стадії за класифікацією В. Х. Василенка та М. Д. Стражеска III-IV ФК (за NYHA). I, основна група, складалась із 120 хворих з перенесеним Q-QS та не Q IM, II група (контрольна) = 40 пацієнтів із перенесеним IM без ознак декомпенсованої СН. Критерієм включення хворих був перенесений не раніше, ніж за 28 діб до початку дослідження, Q-QS та не-Q інфаркт міокарда. Досліджені групи були однорідними за віком, статтю, важкістю перебігу захворювання, тривалістю постінфарктного періоду, наявністю клінічних проявів декомпенсації. Клініч- ний діагноз встановлювали відповідно до рекомендацій Європейського товариства кардіологів на підставі збору анамнезу, фізикального обстеження, даних лабораторно-інструментального дослідження: загальноклінічних аналізів, електрокардіографії, ехокардіографії, рентгенографії органів грудної клітки.

Всім пацієнтам виконано ТШХ, оцінено індивідуальну сприйнятливість до тесту за шкалою Борга, ЕКГ в 12 стандартних відведеннях 3 метою фіксації дестабілізації гемодинаміки, імуноферментне визначення рівня NT-proBNP за допомогою тестнаборів фірми «Діалог Діагнстік» на імунохімічному експрес-аналізаторі Cobash 232 фірми Roche Diagnostics.

Також до та після виконання фізичного навантаження оцінювали частоту серцевих скорочень (ЧСС), рівень систолічного та діастолічного артеріального тиску (АТ) до та після проведення проби. Тест 6-хвилинної ходьби проводився в ранковий час, в лікарняному коридорі, довжиною 30-50 м. Перед початком тесту пацієнт поснідав, не приймав кардіологічних препаратів, не палив та обмежив фізичну активність за 2 години до початку виконання проби.

Перед початком ходи було зафіксовано ЧСС, АТ (систолічний та діастолічний) та виконано ЕКГ в 12 стандартних відведеннях [7].

Протипоказаннями до проведення проби 3 дозованим фізичним навантаженням були: нестабільна стенокардія, інфаркт міокарда упродовж місяця, неконтрольована стенокардія абр артеріальна гіпертензія (САТ >180 мм рт ст, ДАТ >120 мм рт.ст), ЧСС < менше 50 або > 120 за хв, захворювання опорнорухового апарату, інші захворювання, протікання яких може погіршуватись через фізичне навантаження.

Критерії припинення тесту: біль у грудній клітці, важка задишка, судоми кінцівок, запаморочення, похитування під час ходьби, потовиділення, різка блідість, $\mathrm{SpO}_{2}$ менше $86 \%$. За результатами тесту вимірюється пройдена відстань протягом 6 хвилин в метрах (6MWD - 6 Minute Walking Distance) та порівнюється 3 належним показником (6MWD). Також було оцінену шкалу сприйняття навантаження.

Статистична обробка отриманих результатів проводилась 3 допомогою комп'ютерної програми STATISTICA-7 та пакета статистичних функцій програми «Microsoft-Excel» на персональному комп'ютері із застосуванням варіаційностатистичного методу аналізу. В ході роботи було вираховано середнє арифметичне М, середнє квадратичне відхилення $\delta$, середню помилку середньої арифметичної m, число варіанта (n), вірогідність різниці двох середньоарифметичних «р», величини $\mathrm{p}<0,05$ оцінювали вірогідними.

Із метою порівняння вірогідності між групами дослідження щодо появи клінічних ознак та змін при фізикальному обстеженні був використаний точний критерій Фішера.

Результати дослідження. При вивченні клінічних ознак виконання фізичних навантажень було виявлено значне погіршення стану пацієнтів 3 діагнозом Q-QS та не-Q IM, ускладненим декомпенсованою 
CH (Табл. 1). Так, депресія сегменту ST спостерігалась в 67 (55,8\%) пацієнтів, на відміну від групи хворих, де Q-QS та не-Q IM не мав ознак декомпенсованої $\mathrm{CH}$, стенокардія та задишка виникали в $80(66,7 \%)$ та в 75 $(62,5 \%)$ випадків, на відміну від першої групи - 11 $(27,5 \%)$ та $13(32,5 \%)$ обстежених відповідно, симптоми 3 боку центральної нервової системи у вигляді запаморочення та ознаки недостатньої периферичної перфузії (ціаноз/блідість) виникали в 104 (86,7\%) та 79 $(65,8 \%)$ оглянутих, що значно відрізняється від ідентичних показників першої групи - 4 (10\%) та 14 (35\%) досліджених відповідно. Хворі з ознаками декомпенсованої СН в 88 (73,3\%) випадків відчували значну слабкість, втому та висловлювали прохання зупинити пробу.

У результаті аналізу ТШХ було з'ясовано, що наявність декомпенсованої СН значно погіршує показники тесту (Табл. 2).
Так, пройдена дистанція з третьої групи значно нижча, ніж в другій групі, і складає $(174,32 \pm 2,65)$ м $(\mathrm{p} 1<0,05, \quad \mathrm{p} 2<0,05), \quad$ MET $=(1,83 \pm 0,01) \quad(\mathrm{p} 1<0,05$, $\mathrm{p} 2<0,05), \quad$ спожитий $\mathrm{O}_{2}=(11,59 \pm 0,15) \quad(\mathrm{p} 1<0,05$, p2 $<0,05)$ та вірогідно нижча, ніж в першій групі, де дані показники складають $(573,97 \pm 4,51) \mathrm{M},(8,23 \pm 0,02)$ та $(22,93 \pm 0,48)$ відповідно.

Встановлено чітке погіршення індивідуального сприйняття навантаження у хворих 3 ознаками декомпенсованої СН після перенсеного ГІМ (Табл. 3). Більше того, у хворих з неадекватною відповіддю на фізичні навантаження рівень NT-proBNP значно підвищувався і склав $(943,29 \pm 14,99)$ пг/мл $(\mathrm{p} \leq 0,05)$ на піку навантаження.

Клінічні ознаки виконання фізичних навантажень у хворих в постінфарктному періоді залежно від наявності декомпенсованої СН

\begin{tabular}{|c|c|c|}
\hline Ознака & $\begin{array}{c}\text { Хворі на ІМ без декомпенсованої } \\
\mathrm{CH}(\mathrm{n}=40)\end{array}$ & $\begin{array}{c}\text { Хворі на IM з декомпенсованою СН } \\
(\mathrm{n}=120)\end{array}$ \\
\hline Депресія сегменту ST & $10(25 \%)$ & $67(55,8 \%) \mathrm{p}<0,05$ \\
\hline Стенокардія & $11(27,5 \%)$ & $80(66,7 \%) \mathrm{p}<0,05$ \\
\hline Задишка & $13(32,5 \%)$ & $75(62,5 \%) \mathrm{p}<0,05$ \\
\hline Порушення ритму & $9(22,5 \%)$ & $79(65,83 \%) \mathrm{p}<0,05$ \\
\hline Зпаморочення & $4(10 \%)$ & $104(86,7 \%) \mathrm{p}<0,05$ \\
\hline Ціаноз/блідість & $14(35 \%)$ & $79(65,8 \%) \mathrm{p}<0,05$ \\
\hline Втома & $14(35 \%)$ & $88(73,3 \%) \mathrm{p}<0,05$ \\
\hline
\end{tabular}

Примітка: 1. У дужках вказаний відсоток від загальної кількості осіб у групі. 2. $\mathrm{P}$ - вірогідність різниці мі групою хворих із декомпенсованою СН порівняно з хворими без декомпенсованої СН.

Таблиця 2

Результати ТШХ у постінфарктному періоді залежно від наявності декомпенсованої СН

\begin{tabular}{|c|c|c|c|}
\hline $\begin{array}{l}\text { Показник, } \\
\text { од. виміру }\end{array}$ & Здорові $(\mathrm{n}=40)$ & $\begin{array}{l}\text { Хворі на IM без деком- } \\
\text { пенсованої СН }(n=40)\end{array}$ & $\begin{array}{c}\text { Хворі на IM } з \text { декомпенсованою } \\
\text { СН }(n=120)\end{array}$ \\
\hline Пройдена дистанція, м & $573,97 \pm 4,51$ & $\begin{array}{c}383,75 \pm 5,75 \\
\text { p } 1<0,05\end{array}$ & $\begin{array}{c}174,32 \pm 2,65 \\
\text { p1<0,05 p2<0,05 }\end{array}$ \\
\hline Належна дистанція, м & $574,25 \pm 6,25$ & $\begin{array}{l}565,00 \pm 6,88 \\
\text { p } 1<0,05\end{array}$ & $\begin{array}{c}545,95 \pm 5,62 \\
\text { p } 1<0,05 \text { p } 2<0,05\end{array}$ \\
\hline $\begin{array}{l}\text { ЧСС в стані } \\
\text { спокою, м }\end{array}$ & $70,23 \pm 6,37$ & $\begin{array}{c}75,32 \pm 3,41 \\
\text { p } 1<0,05\end{array}$ & $\begin{array}{c}88,2 \pm 3,18 \\
\mathrm{p} 1<0,05 \text { p } 2<0,05\end{array}$ \\
\hline ЧСС після навантаження, м & $77,73 \pm 3,02$ & $\begin{array}{l}89,82 \pm 2,9 \\
\mathrm{p} 1<0,05\end{array}$ & $\begin{array}{c}105,37 \pm 2,82 \\
\mathrm{p} 1<0,05 \mathrm{p} 2<0,05\end{array}$ \\
\hline $\begin{array}{l}\text { САТ в стані } \\
\text { спокою, м }\end{array}$ & $122,03 \pm 8,11$ & $\begin{array}{l}132,00 \pm 8,14 \\
\text { p1 }<0,05\end{array}$ & $\begin{array}{c}161,21 \pm 7,02 \\
\mathrm{p} 1<0,05 \mathrm{p} 2<0,05\end{array}$ \\
\hline САТ після навантаження, м & $129,03 \pm 7,34$ & $\begin{array}{c}150,38 \pm 6,24 \\
\text { p1<0,05 }\end{array}$ & $\begin{array}{c}179,43 \pm 6,02 \\
\mathrm{p} 1<0,05 \mathrm{p} 2<0,05\end{array}$ \\
\hline $\begin{array}{l}\text { ДАТ в стані } \\
\text { спокою, м }\end{array}$ & $78,57 \pm 3,65$ & $\begin{array}{l}91,6 \pm 3,59 \\
\mathrm{p} 1<0,05\end{array}$ & $\begin{array}{c}92,78 \pm 2,18 \\
\mathrm{p} 1<0,05 \mathrm{p} 2<0,05\end{array}$ \\
\hline ДАТ після навантаження, м & $84,22 \pm 2,2$ & $\begin{array}{l}101,83 \pm 2,11 \\
\text { p1<0,05 }\end{array}$ & $\begin{array}{c}103,08 \pm 2,05 \\
\mathrm{p} 1<0,05 \mathrm{p} 2<0,05\end{array}$ \\
\hline MET & $8,23 \pm 0,02$ & $\begin{array}{c}3,89 \pm 0,19 \\
\text { p } 1<0,05\end{array}$ & $\begin{array}{c}1,83 \pm 0,01 \\
\mathrm{p} 1<0,05 \mathrm{p} 2<0,05\end{array}$ \\
\hline Спожитий $\mathrm{O}_{2}$, мл/хв/ $/ \mathrm{M}^{2}$ & $22,93 \pm 0,48$ & $\begin{array}{c}16,09 \pm 0,44 \\
\text { p } 1<0,05\end{array}$ & $\begin{array}{c}11,59 \pm 0,15 \\
\mathrm{p} 1<0,05 \text { p } 2<0,05\end{array}$ \\
\hline
\end{tabular}

Примітка. Вірогідність різниці показників: $\mathrm{p} 1=$ у порівнянні зі здоровими р2 = у порівнянні 3 хворими без ознак декомпенсованої СН. 
Таблиця 3

Шкала індивідуального сприйняття навантаження (Шкала Борга) у хворих в постінфарктному періоді залежно від наявності декомпенсованої СН

\begin{tabular}{|c|c|c|c|}
\hline Ознака & $\begin{array}{c}\text { Здорові } \\
(\mathrm{n}=40)\end{array}$ & $\begin{array}{c}\text { Хворі на ІМ без декомпенсова- } \\
\text { ної СН }(\mathrm{n}=40)\end{array}$ & $\begin{array}{c}\text { Хворі на ІМ з декомпенсованою } \\
(\mathrm{n}=120)\end{array}$ \\
\hline Загальна сума балів & $6,92 \pm 0,01$ & $11,51 \pm 0,49$ & $17,89 \pm 0,13$ \\
& & $\mathrm{p} 1 \leq 0,05$ & $\mathrm{p} 1 \leq 0,05$ \\
& & & $\mathrm{p} 2 \leq 0,05$ \\
\hline
\end{tabular}

Примітка. Вірогідність різниці показників: p1= порівняно зі здоровими, p2 = порівняно з хворими без ознак декомпенсованої СН.

Таблиця 4

Рівень NT-proBNP у постінфарктному періоді залежно від наявності декомпенсованої СН

\begin{tabular}{|c|c|c|}
\hline Показник, од.виміру & $\begin{array}{c}\text { Хворі на IM без декомпенсованої } \\
\text { CH }(\mathrm{n}=40)\end{array}$ & $\begin{array}{c}\text { Хворі на IM } з \text { декомпенсованою СН } \\
(\mathrm{n}=120)\end{array}$ \\
\hline $\begin{array}{l}\text { NT-proBNP пг/мл, до нава- } \\
\text { нтаження }\end{array}$ & $428,5 \pm 6,81$ & $\begin{array}{l}850,54 \pm 20,51 \\
p \leq 0,05\end{array}$ \\
\hline $\begin{array}{l}\text { NT-proBNP пг/мл, після } \\
\text { навантаження }\end{array}$ & $482,25 \pm 12,9$ & $\begin{array}{l}943,29 \pm 14,99 \\
\mathrm{p} \leq 0,05\end{array}$ \\
\hline
\end{tabular}

Примітка: $\mathrm{p}$ = вірогідність різниці показників.

Обговорення результатів. Таким чином, шляхом вивчення особливостей клінічних ознак, толерантності до фізичних навантажень та рівня мозкового натрійуретичного пептиду у хворих 3 діагнозом Q-QS та не-Q IM було встановлено чітку та достовірну відмінність цих показників залежно від наявності ознак декомпенсованої СН.

Найбільш вагомою для клінічної та прогностичної оцінки перебігу постінфарктного періоду, ускладненого декомпенсованою СН, є відповідь організму хворого на дозовані фізичні навантаження та рівень NT-proBNP. У більшості хворих з $\mathrm{CH}$ наявне зниження толерантності до фізичних навантажень.

\section{Висновки:}

1. Підвищення толерантності до фізичного навантаження може сприяти запобіганню формування декомпенсації СН в постінфарктному періоді.

2. Для визначення ступеня змін скоротливості міокарда має місце використання ТШХ.

3. Високі рівні НУП, не зважаючи на оптимальне лікування, вказують на несприятливий прогноз. Тому неадекватна відповідь на дозовані фізичні навантаження та підвищення рівня NT-proBNP, як кількісного маркера $\mathrm{CH}$, може бути корисною не тільки для діагностики, а й для стратифікації ризику, для прийняття рішень про оптимальне лікування такого контингенту хворих і щодо виписки після госпіталізації.

\section{References:}

1. Belegai RI. Osoblyvosti otsinky rezultativ testu $z$ shestychvtlynnoyu khodboyu u khvorykh z khronichnoyu sertsevoyu nedostatnistyu, shcho vunukla na grunti arterialnoyi gipertenziyi z oznakamy metabolichnogo syndromu Galutskyi likarskyi visnyk. 2015; 3(22):19-21.

2. Lyzogub VG, Savchenko OV, Zapeka OV ta in. Zastosuvanya 6-chvylynnogo testy $\mathrm{z}$ chodboyu $\mathrm{V}$ kardiologiyi Pervyi nezavysymyi nauchnyi vestnyk. 2015; 4:12-16.

3. Alba AC, Adamson AA, Macisacc J, Lalonde SD, Chan WS, Deldago DH, MD, MSc, Ross HJ. The added value of exercise variables in heart failure prognosis. $\mathrm{J}$ Card Fail. 2016; 22:492-497.

4. Chambella MC, Mediano MFF, Ferreira RR, Japiassu AM, Waghabi MC, da Silva GMS at all. Correlation of 6minutes walk test with left ventricular function and quality of life in heart failure due to Chagas disease. Tropical Medicine and intarnational health. 2017; 22(10):13141321. Available from: http://scihub.tw/10.1111/tmi.12939. DOI: 10.1111/tmi.12939

5. Corra U, Agostoni PG, Anker SD, Coats AJS, Crespo Leiro MG et all. Role of cardiopulmonary exercise testing in clinical stratification in heart failure. A position paper from the Committee on Exercise Physiology and Training of the Heart Failure Association of the European Society of Cardiology. European Journal of heart failure. 2017; 20(1):3-15. Available from: https://www.ncbi.nlm.nih.gov/pubmed/28925073. DOI: 10.1002/ejhf.979

6. Deboeck G, Van Muylem A, Vachiéry JL et al. Physiological response to the 6-minute walk test in chronic heart failure patients versus healthy control subjects. Eur J Prev Cardiol. 2014; 21(8):997-1003. Available from: https://www.ncbi.nlm.nih.gov/pubmed/. DOI: 10.1177/2047487313482283

7. Demir R, Kucukoglu MS. Six-minute walk test in pulmonary arterial hypertension. The Anatolian Journal of Cardiology. 2015; 15(3):249-254. Available from: https://www.ncbi.nlm.nih.gov/pubmed/25880178. DOI: https://www.ncbi.nlm.nih.gov/pubmed/25880178.

8. Du H, Wonggom P, Tongpeth J et al. Six-minute walk test for assessing physical functional capacity in chronic heart failure. Current Heart Failure Reports. 2017; 14(3):158-166. Available from: https://www.ncbi.nlm.nih.gov/pubmed/28421409. DOI: 10.1007/s11897-017-0330-3

9. Ingle L, Cleland JG, Clarc AL. The relation between repeated 6-minute walk test performance and outcome in patients with chronic heart failure. Ann Phys Rehabil Med. 2014; 57(4):244-253. Available from: https://www.ncbi.nlm.nih.gov/pubmed/24835160. DOI: 10.1016/j.rehab.2014.03.004 
10. Ghashghaei R, Arbit B, Maisel AS. Current and novel biomarkers in heart failure: bench to bedside. Curr Opin Cardiol. 2016, Mar; 31(2):191-5. Available from: https://www.ncbi.nlm.nih.gov/pubmed/29153197 DOI: 10.1097/HCO.0000000000000254.

11. Goenka L, George M, Selvarajan S. End points in heart failure - are we doing it right? European Journal of Clinical Pharmacology. 2017; 73(6):651-659. Available

from:

https:/www.ncbi.nlm.nih.gov/pubmed/28280889 DOI: 10.1007/s00228-017-2228-0.

12. Little WC, Borlaug BA Exercise intolerance in heart failure with preserved ejection fraction What does the heart have do with it? Circulation: Heart Failure. 2015; 8(2):233-35. Available

from: https://www.ncbi.nlm.nih.gov/pubmed/25783946 DOI: 10.1161/CIRCHEARTFAILURE.114.001966.

13. Maisel AS, Duram MJ, Weyyersten N. Natriuretic peptides in heart failure: atrial and B-type natriuretic peptides. Heart Fail Clin. 2018, Jan; 14(1):13-25. Available

from:

https:/www.ncbi.nlm.nih.gov/pubmed/29153197 DOI: 10.1016/j.hfc.2017.08.002.

14. Palau P, Dominguez E, Nunez E, Sanchis J, Santas E, Nunez J. Six-minute walk test in moderate in severe heart failure with preserved ejection fraction: Useful for functional capacity assistmant? International Journal of cardiology. 2016; 203:800-02. Available from: https://www.ncbi.nlm.nih.gov/pubmed/26595788 DOI: https://www.ncbi.nlm.nih.gov/pubmed/26595788.

15. Rostagno C, Gensini GF. Six minute walk test: a simple and useful test to evaluate functional capacity in patients with heart failure. Intern Emerg Med. 2008; 3:205-212. Available from: https://www.ncbi.nlm.nih.gov/pubmed/?term DOI: 10.1007/s11739-008-0130-6.

16. Wolsk E, Kaye D, Borlaug BA, Burkhoff et al. Resting and exercise haemodynamics in relation to six-minute walk test in patients with heart failure and preserved ejection fraction. European Journal of Heart Failure. 2017; 20(4):715-722. Available from: https://www.ncbi.nlm.nih.gov/pubmed DOI: 10.1002/ejhf.976.

17. Zanolla L, Zardini P. Selection of endpoints for heart failure clinical trials. Eur J Heart Fail. 2003; 5(6):717723. Available from: https://www.ncbi.nlm.nih.gov DOI: https://www.ncbi.nlm.nih.gov.

18. Zielińska D, Bellwon J, Rynkiewicz A et al. Prognostic value of the six-minute walk test in heart failure patients undergoing cardiac surgery: a literature review. Rehabil Res Pract. 1-5. 2013. Available from: https://www.ncbi.nlm.nih.gov/pubmed/

DOI: $10.1155 / 2013 / 965494$.

\section{УДК 616-056.2 616.12-008.46+616.127-005.8 \\ ОСОБЕННОСТИ ТОЛЕРАНТНОСТИ К \\ ФИЗИЧЕСКИМ НАГРУЗКАМ В ПОСТИН- \\ ФАРКТНОМ ПЕРИОДЕ В ЗАВИСИМОСТИ ОТ \\ НАЛИЧИЯ ДЕКОМПЕНСАЦИИ ХРОНИЧЕСКОЙ \\ СЕРДЕЧНОЙ НЕДОСТАТОЧНОСТИ}

\section{И.П. Вакалюк, Х.В. Левандовска}

\author{
Ивано-Франковский национальный медицинский \\ университет, кафедра внутренней медиџинь №2 \\ и медсестринства, \\ 2. Ивано-Франковск, Украина, \\ ORCID ID: 0000-0002-4430-6816, \\ ORCIDID: 0000-0003-3259-7940, \\ e-mail:levandovska87@ukr.net
}

Резюме. Цель. Оценить физическую активность и целесообразность использования теста шестиминутной ходьбы у больных с декомпенсированной СН в раннем и позднем постинфарктном периоде на фоне показателей натрийуретического пропептида типа $\mathrm{B}$.

Материалы и методы исследования. Было обследовано 160 пациентов с перенесенным инфарктом миокарда. Больные были рандомизированы в 2 группы в зависимости от наличия признаков декомпенсированной хронической СН. Исследованные группы были однородными по возрасту, полу, тяжести течения заболевания, длительности постинфарктного периода, наличию клинических проявлений декомпенсации.

Результаты исследования и их обсуждение. В течении изучения клинических и электрокардиологический признаков выполнения физических нагрузок, таких как депрессия сегмента ST, стенокардия, одышка, симптомы со стороны центральной нервной системы, было обнаружено значительное ухудшение состояния пациентов с диагнозом Q-QS и не-Q ИМ, осложненным декомпенсированной $\mathrm{CH}$. В результате анализа ТШХ было установлено, что наличие декомпенсированной $\mathrm{CH}$ значительно ухудшает показатели данной нагрузочной пробы. У лиц с признаками декомпенсированной СН имели место достоверно более высокие уровни NT-proBNP в сыворотке крови и составили $(850,54 \pm 20,51)$ пг/мл $(\mathrm{p} \leq 0,05)$ по сравнению с первой группой $(428,5 \pm 6,81) п г /$ мл $(\mathrm{p} \leq 0,05)$.

Выводы. В ходе работы установлено, что неадекватный ответ на дозированные физические нагрузки, высокий уровень NT-proBNP может быть полезным не только для ранней диагностики и прогнозирования возникновения декомпенсированной СН в раннем и позднем постинфарктном периоде, но и для принятия решения об оптимальном дальнейшем диспансерном лечении такого контингента больных и решении о выписке после госпитализации.

Ключевые слова: тест с шестиминутной ходьбой, декомпенсированная сердечная недостаточность, инфаркт миокарда, натрийуретический пропептид типа В. 
UDC 616-056.2 616.12-008.46+616.127-005.8

PECULIARITIES OF EXERCISE TOLERANCE IN THE POST-INFARCTION PERIOD DEPENDING ON THE PRESENCE OF DECOMPENSATED HEART FAILURE

I.P. Vakaliuk, K.V. Levandovska

Ivano- Frankivsk National Medical University, Department of Internal Medicine №2 and Nursing, Ivano-Frankivsk, Ukraine,

ORCID ID: 0000-0002-4430-6816,

ORCIDID: 0000-0003-3259-7940,

e-mail:levandovska87@ukr.net

Abstract. The aim of the study was to evaluate the functional capacity and expediency of using a sixminute walk (SMW) test in patients with decompensated heart failure (HF) in the early and late post-infarction period against the background of indicators of natriuretic propeptide type B.

Materials and methods. There were examined 160 patients with acute myocardial infarction. Depending on the development of decompensated HF in the early and late post-infarction period, the patients have been divided into two subgroups. The major criterion for inclusion of patients to the study was transferred not earlier than 28 days after the beginning of Q-QS and nonQ myocardial infarction. Clinical diagnosis has been made in accordance with the recommendations of the European Society of Cardiologists. The studied groups were homogeneous according to age, sex, severity of the disease, duration of post infarction period, presence of clinical manifestations of decompensation. SMW test, individual susceptibility to Borg scale, CG in 12 standard leads was evaluated for the purpose of fixing hemodynamic destabilization, immuno-enzymatic determination of NT-proBNP level were performed to all patients.
Results of the research and their discussion. During the study of clinical and electrocardiological signs of functional capacity, such as depression of the ST segment, angina pectoris, dyspnea, central and peripheral nervous systems symptoms (dizziness, cyanosis/pallor) and a significant deterioration in the status of patients with Q-QS and non-Q MI complications with complicated decompensated HF, were detected. Because of analyzing six-minute walk test, it was found that the presence of decompensated HF significantly degrades the performance of it. The deterioration has also been found of individual perception of loading in patients with decompensation of HF in the early and late post infarction period. In patients with signs of decompensation in the post infarction period, there were probably higher levels of NT-proBNP in serum and amounted to $(850.54 \pm 20.51)$ $\mathrm{pg} / \mathrm{ml}(\mathrm{p} \leq 0.05)$ compared with the first group $(428.5 \pm 6$, 81) $\mathrm{pg} / \mathrm{ml} \quad(\mathrm{p} \leq 0.05)$. Thus, the most important for the clinical and prognostic estimation of the post infarction period complicated by decompensated HF is the response of the patient's organism to metered physical activity and the level of NT-proBNP.

Conclusions. During the study, it has been found out that an inadequate response to metered physical activity, a high level of NT-proBNP may be useful not only for early diagnosis and prediction of the occurrence of decompensated heart failure in the early and late post infarction period, but also for the decision on optimal further dispensary treatment of such contingent of the patients and decision on discharge after hospitalization. Increasing the tolerance to physical activity can help prevent the formation of decompensation of $\mathrm{HF}$ in the post-infarction period.

Keywords: six-minute walk test, decompensated heart failure, acute myocardial infarction, B-type natriuretic peptide.

Стаття надійшла в редакцію 16.04.2019 р. 